\title{
Software engineering mathematics
}

\section{Presentation}

\section{Author(s):}

Abrial, Jean-Raymond

Publication date:

2005

Permanent link:

https://doi.org/10.3929/ethz-a-004933490

Rights / license:

In Copyright - Non-Commercial Use Permitted

Originally published in:

Einführungsvorlesung von Professorinnen und Professoren / ETH Zürich. Departement Informatik 2005 


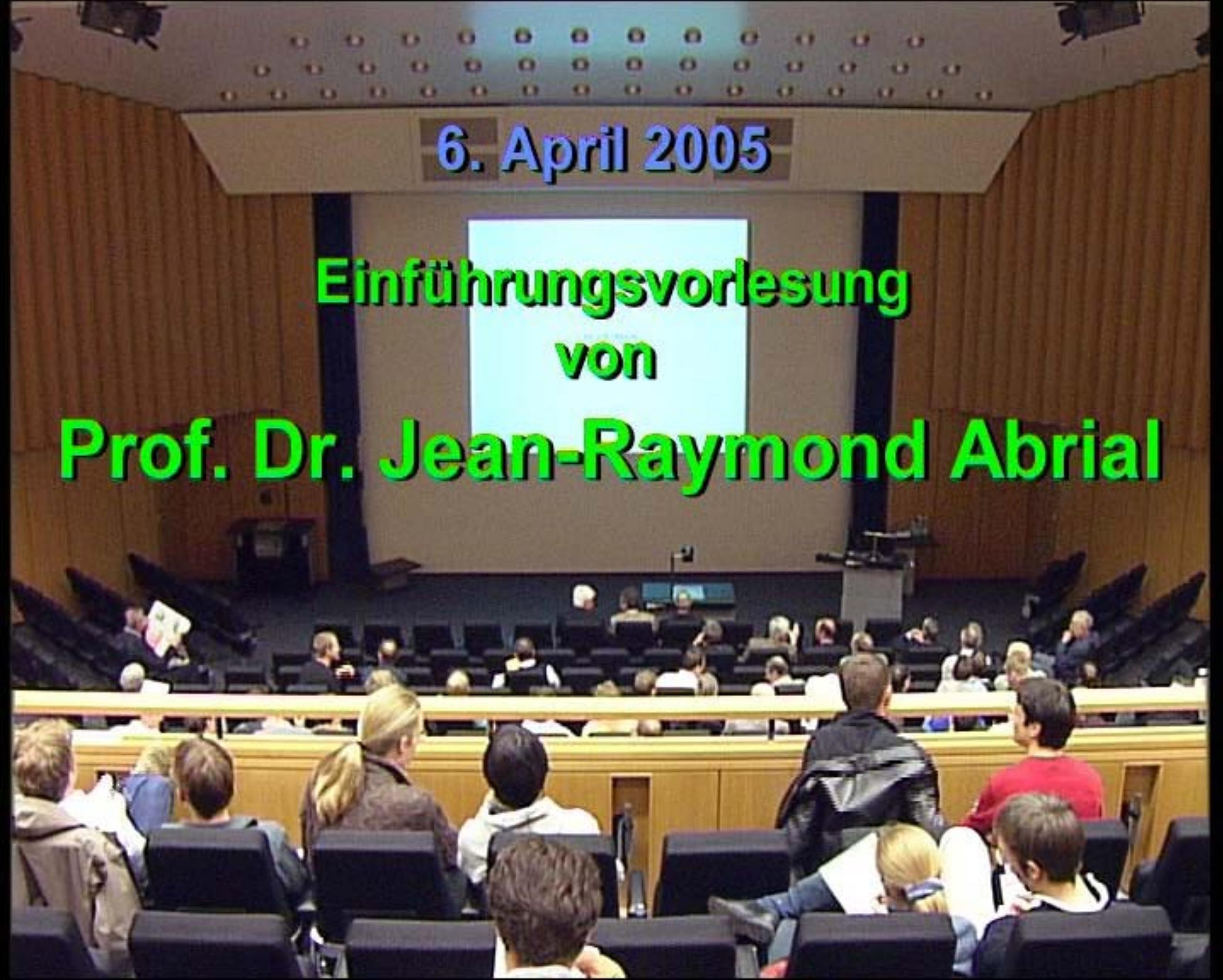

